\title{
US universities face spectre of cuts in military support
}

Washington. A key Congressional committee has called for US Department of Defense (DoD) funding for university research to be halved, from $\$ 1.8$ billion to $\$ 900$ million.

The House defence appropriations subcommittee, chaired by John Murtha (Democrat, Pennsylvania) voted for the draconian cut last week, citing the pain being suffered by the armed forces, and what Murtha sees as the threat of a "hollow force" with highly effective technology but no troops.

The proposed cut will doubtless be modified before the lengthy congressional budget process is completed in September. But the subcommittee proposal, which was approved in a closed meeting, set alarm bells ringing at prominent universities such as Stanford, Massachusetts Institute of Technology (MIT) and the University of Southern California, each of which receives about a quarter of its total federal research support from DoD.

Cornelius Pings, president of the Association of American Universities, which represents the biggest research universities, says that "the impact could be enormous, with some institutions losing tens of millions of dollars".

The universities have many powerful friends, especially in the Senate, and are optimistic that the cut can be reversed. But

congressional staff say that a more likely outcome is a compromise by Murtha, which will still leave the universities facing a substantial loss of income.

Congressional staff also say that one reason for the threatened cut is to fire a warning shot across the bow of House science committee chairman George Brown, who has been campaigning against the habit of appropriations subcommittees of "earmarking" funds to pet projects (see Nature 366, 5; 1993)

In 1991, the last year for which figures are available, the largest recipients of DoD research funding were MIT, with $\$ 55$ million, Pennsylvania State University ( $\$ 30$ million) and Stanford (\$29 million).

Johns Hopkins University received $\$ 260$ million from DoD to run the Applied Physics Laboratory near Baltimore, Maryland. But that is categorized as development work and, according to a university spokesman, is not thought to be subject to the proposed cut.

The Murtha subcommittee budget was passed on Monday by the full appropriations committee chaired by David Obey (Democrat, Wisconsin), and was due to be considered later this week by the House of Representatives as a whole.

Colin Macilwain

\section{Recession hits European patents}

Munich. To judge by patent applications received last year by the European Patent Office (EPO), the economic recession of the past few years has been taking its toll on innovation, with only the United States managing to register an increase in its innovative potential.

The overall number of applications to the EPO fell from its peak of over nearly 59,000 in 1992 to 57,000 last year. The United States filed 29 per cent of this number, compared to 27 per cent in 1992; in contrast, while Japan's share of the total dropped from nearly 19.5 per cent to 18 per cent.

The share of applications filed by the EPO's 17 member states fell from $\mathbf{4 9 . 3}$ per cent to 48.6 per cent, despite efforts by governments to beat the recession through national innovation policies.

Italy, France and the Netherlands fared particularly badly, each filing around 10 per cent fewer applications than in 1992, while even Germany's healthy record of 11,500 applications in 1992 fell by five per cent. The United Kingdom maintained its rather low share of around 3,100 applications (around 5.5 per cent of the total received by the EPO).

A. A.
$30 \%$

\section{Distribution of patents awarded by the European Patent Office}

$10 \%$

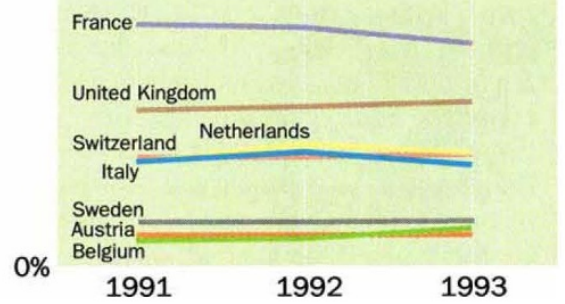

Allain loses appeal and faces threat of new charges

Paris. A leading French haemotologist who was given a four-year prison sentence (with two years suspended) for his involvement in a blood contamination scandal in the mid1980 s, last week lost his appeal to the Paris Supreme Court of Appeals.

The formulation of the court's ruling may also open the way to further charges of "poisoning" being brought against JeanPierre Allain, who formerly worked for the French National Centre for Blood Transfusion (CNTS).

Allain had appealed to the Supreme Court on the grounds that he should never have been convicted in 1992 under a 1901 law on "deception over the quality of the products he sold", after losing an appeal last summer in a lower court against that 1992 verdict.

The lawyer representing Allain, Olivier Schnerb, had also argued that, as Allain had worked in the research department of the CNTS, he had not been involved in distribution of contaminated blood products to haemophiliacs.

The court rejected Allain's appeals the Supreme Court judges on the legal basis of a trial, and not the verdict - as well as 14 civil suits calling for Allain to be tried instead on the charge of poisoning, in a criminal court, along with three other officials convicted with Allain.

Of the three, Michel Garretta, the former director-general of CNTS, had received a four-year prison sentence and a FF500,000 fine on the same charge as Allain. The other two, Jacques Roux, former director-general of health at the National Ministry of Health, and Robert Netter, former head of the National Laboratory, had received three- and one-year suspended prison sentences respectively for "non-assistance to persons in danger".

Max Lecocq, a young haemophiliac, indicated after last week's appeal that he would bring poisoning charges against Garretta and Allain and "all the others". Lecocq has already brought charges of poisoning against three others who were ministers at the time, Laurent Fabius, prime minister, Georgina Dufoix, minister of social affairs, and Edmond Hervé, secretary of state for health (see Nature 367, 304; 1994).

Many in the judiciary, however, are likely to resist fiercely the idea that someone could be tried on different charges for the same act. But one thing seems certain - that Garretta and Allain will serve the full length of their sentences. Although most prisoners are released half-way through their term, the justice minister, Pierre Méhaignerie, said in a radio interview earlier this week that both should serve their full terms.

Declan Butler 